\title{
Pencapaian Hasil Belajar Biologi dengan Model Problem Based Learning (PBL) dan Model Kooperatif Tipe Student Teams-Achievement Divisions (STAD) Ditinjau dari Minat Belajar Peserta Didik Sekolah Menengah Atas Negeri di Kabupaten Grobogan
}

\author{
Ririk Niangkasawati16, Mulyoto17, Deny Tri Ardianto18 \\ riexangkasa@gmail.com
}

\begin{abstract}
The objectives of this research are to investigate: (1) the difference of effect between the PBL model and the cooperative learning model of the STAD type on the Biology learning outcome of the students of Senior Secondary Schools of Grobogan Regency; (2) the difference of effect between the high learning interest and the low learning interest on the Biology learning outcome of the students of Senior Secondary Schools of Grobogan Regency; (3) and the interaction of effect between the learning models and the learning interests on the Biology learning outcome of the students of Senior Secondary Schools of Grobogan Regency. This research used the experimental research method with the factorial design of 2x2. It was conducted at Senior Secondary Schools of Grobogan Regency. The results of this research are as follows: (1) there was a significant difference of effect between the PBL model and the cooperative learning model of the STAD type on the Biology learning outcome of the students of Senior Secondary Schools of Grobogan Regency where the former had a better effect on the Biology learning outcome than the latter as indicated by the result of the two-way analysis of variance (ANOVA) in which the F-value was 4.669 and the p-value was smaller than 0.05; (2) there was a significant difference of effect between the high learning interest and the low learning interest on the Biology learning outcome of the students of Senior Secondary Schools of Grobogan Regency where the former had a better effect on the Biology learning outcome than the latter as indicated by the result of the twoway analysis of variance (ANOVA) in which the F-value was 5.554 and the p-value was smaller than 0.05; and (3) there was an interaction of effect between the learning models and the learning interests on the Biology learning outcome of the students of Senior Secondary Schools of Grobogan Regency as indicated by the result of the two-way analysis of variance (ANOVA) in which the F-value was 4.434 , and the p-value was smaller than 0.05. The highest average score in Biology learning of the students with the PBL model and with the high leaning interest was 83.88, whereas the lowest score in Biology learning of the students with the PBL model and with the low learning interest was 74. 47.
\end{abstract}

Keywords: The PBL model, the cooperative learning model of the STAD type, Biology learning outcome, learning interest

\footnotetext{
${ }^{16}$ Alumni Magister Teknologi Pendidikan Universitas Sebelas Maret Surakarta

17 Dosen Universitas Sebelas Maret Surakarta

18 Dosen Universitas Sebelas Maret Surakarta 


\section{PENDAHULUAN}

$\mathrm{M}$ asalah yang dihadapi dalam dunia pendidikan kita adalah lemahnya proses pembelajaran. Dalam proses pembelajaran peserta didik didorong untuk mengembangkan kemampuan berpikir. Proses pembelajaran di dalam kelas mengarahkan kemampuan anak untuk menghafal informasi, mengingat berbagai informasi tanpa dituntut untuk memahami informasi yang diingatnya itu untuk menghubungkannya dengan kehidupan sehari-hari (Sanjaya, 2006).

Biologi sebagai salah satu bidang studi IPA (IImu Pengetahuan Alam) merupakan suatu ilmu yang besar perannya dalam pendidikan. Belajar Biologi sangat bermanfaat bagi kehidupan sehari-hari. Begitu pentingnya peranan Biologi maka Pemerintah berupaya untuk meningkatkan mutu pengajaran mulai dari tingkat Sekolah Menengah Pertama (SMP) sampai ke Perguruan Tinggi. Kualitas pendidikan tidak terlepas dari pencapaian hasil atau prestasi belajar peserta didik, karena hasil belajar peserta didik dapat dijadikan tolok ukur untuk menilai apakah pendidikan disuatu sekolah berhasil atau tidak.

Tujuan pembelajaran Biologi mengharapkan peserta didik dapat mengetahui, memahami, menyimpulkan, menganalisis, dapat memecahkan masalah dan mampu mengaplikasikan pemahaman mereka dalam kehidupan sehari-hari. Tujuan pembelajaran Biologi ini seharusnya dapat dicapai seluruh peserta didik, jika dalam proses belajar guru mampu membuat perencanaan atau menggunakan model pembelajaran yang efisien, efektif untuk menumbuhkan minat peserta didik dalam belajar dan terjadinya interaksi antara guru dengan peserta didik dan peserta didik dengan peserta didik dengan cara melakukan presentasi pendapat dan tanya jawab, melakukan diskusi sesama peserta didik, memberikan pertanyaan dalam bentuk masalah yang dapat memacu minat belajar peserta didik sehingga pembelajaran di kelas akan membentuk peserta didik yang aktif dan memperoleh hasil belajar yang lebih baik.

Hasil belajar adalah kemampuan-kemampuan yang dimiliki peserta didik setelah menerima pengalaman belajarnya (Sudjana, 2004). Menurut Syah (2004), "Proses belajar dapat diartikan sebagai tahapan perubahan perilaku kognitif, afektif, dan psikomotor yang terjadi dalam diri peserta didik". Perubahan tersebut bersifat positif dalam arti berorientasi kearah yang lebih maju daripada keadaan sebelum.

Biologi berasal dari bahasa Yunani, bios yang artinya hidup dan logos yang berarti ilmu. Jadi, biologi adalah cabang IImu Pengetahuan Alam (IPA) atau sains yang mempelajari khusus tentang seluk beluk kehidupan. Cakupan kajian biologi meliputi makhluk hidup, zat-zat penyusun tubuh makhluk hidup, zat, energi yang dibutuhkan makhluk hidup, dan segala hal yang berkaitan dengan kehidupan yang ada dipermukaan bumi (Prawirohartono, 2004).

Biologi lahir dan berkembang melalui pengamatan dan eksperimen. Biologi dapat dikembangkan melalui cara yang teratur dengan menggunakan metode ilmiah. Metode ilmiah itu sendiri merupakan tahap-tahap pengembangan ilmu yang dilakukan secara sistematis dengan menggunakan logika. Metode ilmiah mengandung kejujuran secara mutlak baik dalam berpikir atau bertindak dan disiplin yaitu ketaatan dalam semua langkah kerja.

\section{Problem Based Learning}

Abbas (2000), menyatakan bahwa "Model Pembelajaran Problem Based Learning (PBL) adalah model pembelajaran dengan pendekatan pembelajaran peserta didik pada masalah autentik, sehingga peserta didik dapat menyusun pengetahuannya sendiri dan keterampilan yang lebih tinggi, inkuiri, memandirikan peserta didik, dan meningkatkan kepercayaan diri sendiri".

Menurut Sanjaya, (2011) keunggulan Model Pembelajaran Problem Based Learning,yaitu:

1. $P B L$ merupakan model pembelajaran yang cukup bagus untuk lebih memahami isi pelajaran, 
2. Pemecahan masalah dapat menantang kemampuan peserta didik serta memberikan kepuasaan untuk menemukan pengetahuan baru bagi peserta didik,

3. Dapat meningkatkan aktivitas pembelajaran peserta didik,

4. Dapat membantu peserta didik untuk membentuk pengetahuan mereka untuk memahami masalah dalam kehidupan nyata,

5. Dapat membantu peserta didik untuk mengembangkan pengetahuan barunya dan bertanggung jawab dalam pembelajaran yang mereka lakukan,

6. Dapat mendorong untuk melakukan evaluasi sendiri baik terhadap hasil maupun proses belajarnya,

7. Dapat memperlihatkan kepada peserta didik bahwa setiap mata pelajaran (Matematika, IPA, Sejarah dan lain-lain) pada dasarnya memerlukan cara berpikir dan sesuatu yang harus dimengerti oleh peserta didik, bukan hanya sekedar belajar dari guru atau buku-buku saja,

8. $P B L$ dianggap lebih menyenangkan dan disukai peserta didik,

9. Dapat mengembangkan kemampuan peserta didik berpikir kritis dan mengembangkan kemampuan mereka untuk menyesuaikan dengan pengetahuan baru,

10.Dapat memberikan kesempatan kepada peserta didik untuk mengaplikasikan pengetahuan yang mereka miliki dalam dunia nyata, dan dapat mengembangkan minat peserta didik untuk secara terus-menerus belajar sekalipun belajar pada pendidikan formal telah berakhir.

Kelemahan yang terdapat dalam Model Pembelajaran PBL yaitu 1. Manakala peserta didik tidak memiliki minat atau tidak mempunyai kepercayaan bahwa masalah yang dipelajari sulit untuk dipecahkan, maka mereka akan merasa enggan untuk mencoba, 2. keberhasilan strategi pembelajaran melalui $P B L$ membutuhkan cukup waktu untuk persiapan, 3. Tanpa pemahaman mengapa mereka berusaha untuk memecahkan masalah yang sedang dipelajari, maka mereka tidak akan belajar apa yang seharusnya mereka pelajari" (Sanjaya, 2011).

\section{Model Kooperatif Tipe STAD}

Tipe Student Team Achievement Divisions (STAD) atau Pembagian Pencapaian Tim Peserta didik dikembangkan oleh Slavin. Menurut Slavin (2005) Student Team Achievement Devisions (STAD) adalah satu tipe pembelajaran kooperatif yang paling sederhana. STAD merupakan salah satu tipe kooperatif yang menekankan pada adanya aktivitas dan interaksi diantara peserta didik untuk saling memotifasi dan saling membantu dalam menguasai materi pelajaran. Model ini menempatkan peserta didik dalam tim belajar beranggotakan empat orang yang merupakan campuran menurut tingkat kinerjanya, jenis kelamin dan suku.

\section{Minat Belajar}

Minat merupakan masalah yang paling penting di dalam pendidikan, apalagi bila dikaitkan dengan aktivitas seseorang dalam kehidupan sehari-hari. Minat yang ada pada diri seseorang akan memberi gambaran dalam aktivitas untuk mencapai suatu tujuan.Minat merupakan suatu keinginan yang dimiliki oleh seseorang secara sadar.

Menurut Sardiman (2001) "Minat diartikan sebagai suatu kondisi yang terjadi apabila seseorang melihat ciri-ciri atau arti sementara suatu situasi yang dihubungkan dengan keinginan - keinginan atau kebutuhan-kebutuhannya sendiri. Seseorang yang berminat terhadap suatu aktifitas akan memperhatikan aktifitas itu secara konsisten dengan rasa senang. Syah (2004) minat (interest) berarti kecenderungan dan kegairahan yang tinggi atau keinginan yang besar terhadap sesuatu 
Minat mempunyai peranan yang sangat penting dalam perkembangan belajar peserta didik. Peserta didik yang menaruh minat pada suatu bidang tertentu, maka akan berusaha lebih keras dalam menekuni bidang tersebut dibanding peserta didik yang tidak menaruh minat. Slameto (2010) berpendapat bahwa minat adalah suatu rasa lebih suka dan rasa keterikatan pada suatu hal atau aktivitas, tanpa ada yang menyuruh. Minat pada dasarnya adalah penerimaan akan suatu hubungan antara diri sendiri dengan sesuatu di luar diri. Suatu minat dapat diekspresikan melalui suatu pernyataan yang menunjukkan bahwa peserta didik lebih menyukai suatu hal daripada hal lainnya, dapat pula dilihat melalui partisipasi dalam suatu aktivitas

\section{Tujuan Penelitian}

Tujuan penelitian ini adalah (1) untuk mengetahui perbedaan pencapaian antara model Problem Based Learning dan model kooperatif tipe STAD (Student Team Achievement Division) terhadap hasil belajar peserta didik SMA Negeri di Kabupaten Grobogan, (2) untuk mengetahui perbedaan minat belajar tinggi atau minat belajar rendah terhadap pencapaian hasil belajar biologi peserta didik SMA Negeri di Kabupaten Grobogan, (3) untuk mengetahui interaksi model pembelajaran Problem Based Learning dan model kooperatif tipe STAD dengan minat belajar peserta didik terhadap pencapaian hasil belajar biologi SMA Negeri di Kabupaten Grobogan.

\section{METODE PENELITIAN}

\section{Tempat dan Waktu Penelitian}

Penelitian ini dilaksanakan di SMA Negeri 1 Wirosari dan SMA Negeri 1 Kradenan selama 3 bulan.

\section{Desain dan Sampel Penelitian}

Penelitian dilakukan dengan metode eksperimen dengan desain faktorial $2 \times 2$. Teknik pengambilan sampel adalah Multistage Cluster Random Sampling dengan langkah-langkah sebagai berikut:

1) Dari 11 SMA Negeri di Kabupaten Grobogan secara random dipilih 2 SMA Negeri yaitu SMA Negeri 1 Wirosari dan SMA Negeri 1 Kradenan,

2) Dari 2 SMA Negeri tersebut, secara random ditentukan SMA Negeri yang menjadi kelompok eksperimen satu yaitu SMA Negeri 1 Wirosari (belajar dengan model PBL) dan eksperimen dua yaitu SMA Negeri 1 Kradenan (belajar dengan model kooperatif tipe STAD), untuk pengujian instrumen dilakukan uji coba pada SMA Negeri 1 Gabus

3) Untuk kelas penelitian yaitu kelas $X$ karena materi yang akan disampaikan adalah materi kelas $X$ dan didasarkan pada pertimbangan bahwa fakta yang ditemui di lapangan bahwa model yang digunakan guru masih terpusat pada pembelajaran satu arah dan hasil belajar peserta didik yang diperoleh masih rendah .

\section{Teknik Pengambilan Data}

Instrumen pengumpulan data yang digunakan pada penelitian ini meliputi tes hasil belajar dan angket minat belajar. Tes digunakan untuk memperoleh data hasil belajar sebanyak 26 soal dan angket minat belajar sebanyak 23 item 
Kedua instrumen tersebut sudah diuji dan layak untuk digunakan untuk penelitian. Tes hasil belajar secara konstruk diuji validitas tiap itemnya dengan bantuan Micro Computer Adaptive Test (MicroCat) dan point biserial correlation sedangkan angket minat belajar diuji validitasnya tiap itemnya dengan Product moment correlation dan diuji reliabilitasnya dengan teknik cronbachs alpha.

\section{Teknik Analisis Data}

Data penelitian dianalisis dengan tahap-tahap sebagai berikut: 1) uji prasyarat analisis, yang terdiri atas uji normalitas dengan metode liliefors(kolmogorov-smirnovc), dan uji homogenitas variansi dengan teknik levene's test, 2) uji hipotesis, yang terdiri atas analisis variansi dua jalan (two-way anova) dan uji lanjut dengan teknik scheffe test.

\section{HASIL PENELITIAN DAN PEMBAHASAN}

\section{Hasil Penelitian}

Sesuai dengan desain faktorial $2 \times 2$, sampel dibagi menjadi 2 kelompok berdasarkan model pembelajaran, menjadi 2 kelompok berdasarkan minat belajar, dan menjadi 4 kelompok berdasarkan kombinasi kedua faktor tersebut. Nilai-nilai statistik deskriptif hasil belajar biologi pada tiap-tiap kelompok dapat dilihat pada tabel 1.

Rata-rata nilai hasil belajar pada peserta didik yang belajar dengan model pembelajaran PBL $\left(A_{1}\right)$ adalah sebesar 81,08 dan pada peserta didik yang belajar dengan model pembelajaran kooperatif tipe $\operatorname{STAD}\left(\mathrm{A}_{2}\right)$ adalah sebesar 74,62 . Hal ini menunjukkan bahwa secara deskrip-tif hasil belajar peserta didik yang belajar dengan model PBL lebih baik dibandingkan hasil belajar siswa yang belajar dengan model kooperatif tipe STAD.

Tabel 1. Deskripsi Data Hasil Belajar Biologi

\begin{tabular}{|c|c|c|c|c|c|}
\hline \multirow{2}{*}{$A$} & \multirow[t]{2}{*}{ B } & \multirow{2}{*}{$\begin{array}{c}\text { Sumber } \\
\text { Statisti } \\
\text { k }\end{array}$} & \multicolumn{2}{|c|}{ Minat Belajar } & \multirow[t]{2}{*}{ Total } \\
\hline & & & $\begin{array}{c}\text { Tinggi } \\
\left(B_{1}\right)\end{array}$ & Rendah $\left(B_{2}\right)$ & \\
\hline Model & PBL & $\mathrm{N}$ & 26 & 11 & 37 \\
\hline \multirow[t]{14}{*}{ Pembelajaran } & $\left(A_{1}\right)$ & Min & 61,54 & 65,38 & 61,54 \\
\hline & & Max & 100,00 & 80,77 & 100,00 \\
\hline & & Mean & 83,88 & 74,47 & 81,08 \\
\hline & & SD & 9,17 & 4,95 & 9,17 \\
\hline & STAD & $\mathrm{N}$ & 17 & 18 & 35 \\
\hline & $\left(A_{2}\right)$ & Min & 61,54 & 61,54 & 61,54 \\
\hline & & Max & 92,31 & 92,31 & 92,31 \\
\hline & & Mean & 74,89 & 74,36 & 74,62 \\
\hline & & SD & 8,95 & 8,83 & 8,76 \\
\hline & Total & $\mathrm{N}$ & 43 & 29 & 72 \\
\hline & & Min & 61,54 & 61,54 & 61,54 \\
\hline & & Max & 100,00 & 92,31 & 100,00 \\
\hline & & Mean & 80,32 & 74,40 & 77,94 \\
\hline & & SD & 9,97 & 7,57 & 9,49 \\
\hline
\end{tabular}

Rata-rata nilai hasil belajar pada peserta didik yang memiliki minat belajar tinggi adalah sebesar 80,32 dan pada peserta didik yang memiliki minat belajar rendah adalah sebesar 74,40 . Hal ini 
menunjukkan bahwa secara deskriptif hasil belajar peserta didik yang memiliki minat tinggi lebih baik dibandingkan hasil belajar siswa yang memiliki minat rendah.

Terdapat 4 kelompok sampel aktual dalam eksperimen ini. Kelompok peserta didik yang belajar dengan model pembelajaran PBL dan memiliki minat belajar tinggi $\left(A_{1} B_{1}\right)$ meraih hasil belajar dengan rata-rata nilai tertinggi yaitu 83,88 . Kelompok siswa yang juga memiliki minat belajar tinggi namun belajar dengan model pembelajaran kooperatif tipe STAD $\left(A_{2} B_{1}\right)$ meraih hasil belajar dengan rata-rata nilai tertinggi kedua yaitu 74,89 . Kelompok peserta didik yang memiliki minat belajar rendah baik belajar dengan model pembelajaran PBL $\left(A_{1} B_{2}\right)$ maupun tipe STAD $\left(A_{2} B_{2}\right)$ meraih hasil belajar dengan rata-rata nilai terendah yaitu masing-masing 74,62 dan 74,40 .

Data sampel pada semua kelompok dinyatakan berdistribusi normal dan variansi data sampel antar kelompok dinyatakan homogen. Dengan demikian syarat penggunaan analisis variansi dua jalan dan scheffe test terpenuhi. Hasil pengujian hipotesis dapat dilihat pada tabel 2.

Hasil pengujian statistik dalam analisis variansi menunjukkan bahwa variasi atau perbedaan hasil belajar biologi yang disebabkan ketiga sumber variasi dinyatakan signifikan $(p<0,05)$. Dengan demikian dapat disimpulkan bahwa model pembelajaran dan minat belajar masing-masing berpengaruh signifikan terhadap hasil belajar biologi. Selain itu disimpulkan juga bahwa kedua faktor tersebut memiliki interaksi dalam pengaruhnya terhadap hasil belajar.

Tabel 2. Uji Hipotesis dengan Uji Two-Way Anova

\begin{tabular}{ccccccc}
\hline Sumber & JK & Dk & RK & F & P & Keterangan \\
\hline Model (A) & 340,130 & 1 & 340,130 & 4,669 & 0,034 & Signifikan \\
Minat Belajar (B) & 404,561 & 1 & 404,561 & 5,554 & 0,021 & Signifikan \\
Interaksi AB & 322,987 & 1 & 322,987 & 4,434 & 0,039 & Signifikan \\
Galat & 4953,562 & 68 & & & & \\
Total & 443742,166 & 72 & & & & \\
\hline
\end{tabular}

\section{Pembahasan}

Pengujian pertama analisis variansi menunjukkan bahwa model pembelajaran berpengaruh signifikan terhadap hasil belajar Biologi $(p=0,005)$. Penerapan model PBL (mean $=81,08$ ) menghasilkan hasil belajar biologi lebih baik dibandingkan model kooperatif tipe STAD (mean $=74,62$ ).

Pengujian kedua analisis variansi menunjukkan bahwa minat belajar berpengaruh signifikan terhadap hasil belajar Biologi $(p=0,000$ ). Peserta Didik dengan minat belajar tinggi (mean $=80,32$ ) memiliki hasil belajar biologi lebih baik dibandingkan peserta didik dengan minat belajar rendah (mean = 74,40).

Pengujian ketiga analisis variansi menunjukkan bahwa terdapat interaksi model pembelajaran dan minat belajar dalam mempengaruhi hasil belajar biologi $(p=0,039)$. Penerapan model pembelajaran baik PBL maupun Kooperatif tipe STAD pada peserta didik dengan minat belajar rendah tidak akan memberikan pengaruh baik pada hasil belajar. Kedua model tepat diterapkan pada peserta didik dengan minat belajar tinggi di mana model $P B L$ (mean $=83,88$ ) akan menghasilkan hasil belajar Biologi yang lebih baik dibandingkan model kooperatif tipe STAD (mean $=74,89)$.

\section{SIMPULAN}


1. Terdapat perbedaan pencapaian yang signifikan hasil belajar Biologi pada kelompok dengan menggunakan model PBL dan kelompok kooperatif tipe STAD. Hasil belajar peserta pada mata pelajaran Biologi dengan model PBL lebih baik dari pada peserta didik yang menggunakan model STAD.

2. Terdapat perbedaan pencapaian yang signifikan hasil belajar Biologi pada kelompok peserta didik dengan minat belajar tinggi dan kelompok peserta didik dengan minat belajar rendah. Hasil belajar peserta didik pada mata pelajaran Biologi yang memiliki minat belajar tinggi lebih baik dari pada peserta didik yang memiliki minat belajar rendah.

3. Terdapat interaksi antara model pembelajaran dengan minat belajar terhadap pencapaian hasil belajar Biologi. Hasil belajar pada mata pelajaran Biologi pada kelompok model PBL dengan minat belajar tinggi mempunyai nilai rata-rata tertinggi, sedangkan kelompok model STAD dengan minat belajar rendah mempunyai nilai rata-rata terendah

\section{DAFTAR PUSTAKA}

Abbas, N. (2000). Penerapan Model Pembelajaran Berdasarkan Masalah (Problem Based Instruction) dalam pembelajaran Matematika di SMU. (Online) tersedia : http://www.depdiknas.go.id/jurna;/S1/040429\% 20-ed-20\% nurhayati-penerapan $\% 20 \%$ model\%pemeblajaran.pdf.

Prawirohartono, S \& Hidayati, S. (2004). Sains Biologi 1 Untuk SMA Kelas X. Jakarta: PT. Bumi Aksara

Sanjaya, W. (2011). Strategi Pembelajaran Berorientasi Standar Proses Pendidikan. Jakarta : Kencana Prenda Media Group

Sardiman. (2001). Interaksi dan Motivasi Belajar Mengajar. Jakarta: Rajawali.

Sudjana, N. (2004). Penilaian Hasil Proses Belajar Mengajar. Bandung: Rosda karya

Sugiyono. (2012). Model Penelitian Tindakan Pendekatan Kuantitatif, Kualitatif dan R\&D. Bandung: Alfabeta.

Suryabrata, S. (2002). Psikologi Pendidikan. Jakarta: Rineka Cipta

Slameto. (2010). Belajar dan Faktor yang Mempengaruhinya. Jakarta: Rineka Cipta

Slavin. (2005). Cooperative Learning: Teori, Riset, dan Praktik. Bandung: Nusa Media

Syah, M. (2004). Psikologi Pendidikan Dengan Pendekatan Baru. Bandung: Remaja Rosdakarya. 